\title{
PERBANDINGAN STRATEGI INKUIRI TERBIMBING DENGAN PROBLEM SOLVING TERHADAP PEMAHAMAN KONSEPTUAL DAN ALGORITMA SISWA DENGAN KEMAMPUAN BERPIKIR ILMIAH RENDAH
}

\author{
Rendy Priyasmika \\ Program Studi Pendidikan Kimia, FKIP, Universitas Billfath \\ rendy.priyasmika@gmail.com
}

\begin{abstract}
Abstrak
Salah satu materi kimia SMA yang berisi konsep konkrit, abstrak dan melibatkan perhitungan matematika adalah kelarutan dan hasil kali kelarutan $\left(K_{\mathrm{sp}}\right)$. Pemahaman konseptual dinyatakan dengan kalimat pendek sedangkan pemahaman algoritma dinyatakan dengan persamaan matematika. Keduasaling barkaitan, sehingga untuk pembelajaran perlu strategi yang tepat. Strategi pembelajaran inkuiri terbimbing dan Problem Solving diduga ampu tingkatkan konseptual dan pemahaman algoritma siswa dengan Kemampuan Berpikir Ilmiah Rendah (KBIR). Tujuan penelitian ini mengetahui perbedaan dan pemahaman algoritma siswa dengan KBIR yang dibelajarkan dengan strategi inkuiri terbimbing dan Problem Solving. Rancangan yang digunakan ialah eksperimen semu dengan posttest only control group design. Data hasil tes pemahaman konseptual dan algoritma diperoleh dari tes menggunakan 20 soal pilihan ganda dengan nilai koefisien reliabilitas sebesar 0,71 dan validitas isi sebesar $93,17 \%$. Analisis data menggunakan uji t dan korelasi Product Moment pada taraf signifikansi 5\%. Hasil penelitian menunjukkan bahwa hasil belajar siswa KBIR yang menggunakan strategi inkuiri terbimbing lebih tinggi dibandingkan dengan siswa yang menggunakan strategi Problem Solving dan pemahaman algoritma siswa dengan KBIR lebih tinggi dibandingkan pemahaman konseptualnya baik menggunakan strategi inkuiri terbimbing maupun dengan strategi Problem Solving.
\end{abstract}

Kata Kunci: inkuiri terbimbing, problem solving, pemahaman konseptual, pemahaman algoritma, kemampuan berpikir ilmiah

\begin{abstract}
One of the high school chemistry materials that contains concrete concepts, abstracts and involves mathematical calculations is solubility and solubility product $(K s p)$. Conceptual understanding is usually expressed in short sentences while understanding algorithms is expressed by mathematical equations. Both of these understandings are closely related to one another so that to teach them requires the right learning strategies. Guided inquiry learning strategies and Problem Solving are thought to be able to improve the conceptual understanding and algorithm understanding of students with Low Scientific Thinking Ability. This study aims to determine differences in conceptual understanding with algorithm understanding of students with KBIR that are taught with guided inquiry strategies and Problem Solving. This study uses a quasi-experimental design with posttest only control group design. Data from the conceptual understanding and algorithm test results obtained from the test using 20 multiple choice questions with a reliability coefficient of 0.71 and content validity of $93.17 \%$. Data analysis using $t$ test and Product Moment correlation at a significance level of 5\%. The results show that The learning outcomes of student with low scientific thinking ability that learned by guided inquiry's strategy is higher than the students that learned by problem solving's strategy and The understanding of algorithms of students with low scientific thinking ability is higher than conceptual understanding both of which that learned by guided inquiry strategies and problem solving strategies.
\end{abstract}

Keywords: guided inquiry, problem solving, conceptual understanding, algorithm understanding, scientific thinking ability

\section{PENDAHULUAN}

Ilmu kimia merupakan salah satu cabang dari ilmu pengetahuan alam (IPA) yang mempelajari tentang gejala alam dan berbagai peristiwanya dengan serangkaian kegiatan observasi dan eksperimen, 
sehingga didapatkan konsep-konsep baru. Selain itu, ilmu kimia dalam IPA mempelajari tentang sifat materi, struktur materi, perubahan materi, hukum dan prinsip yang mendeskripsikan perubahan materi, serta konsep dan teorinya (Effendy, 2006:1). Konsep-konsep yang tercakup dalam ilmu kimia bersifat konkrit, abstrak, dan prosedural, sehingga diperlukan pemahaman yang baik untuk mempelajarinya.

Kelarutan dan hasil kali kelarutan $\left(K_{\mathrm{sp}}\right)$ merupakan salah satu materi kimia yang mengandung pemahaman konseptual dan pemahaman algoritma yang diajarkan di SMA untuk siswa kelas XI IPA. Materi ini mencakup konsep-konsep penting diantaranya kelarutan, hasil kali kelarutan, faktor-faktor yang mempengaruhi kelarutan (pengaruh adanya ion senama dan pengaruh $\mathrm{pH})$, dan pengendapan. Tacettin \& Canpolat (2003) mengemukakan bahwa materi kelarutan dan hasil kali kelarutan mempunyai karakteristik konsep konkrit, abstrak, dan algoritmik. Karakteristikkarakteristik tersebut menimbulkan konsekuensi yaitu membutuhkan lebih dari satu cara dalam representasinya.

Konsep materi kelarutan dan hasil kali kelarutan dibangun dari hasil pengamatan dan observasi. Kesimpulan dari observasi ada yang dinyatakan dengan kalimatkalimat sederhana yang dalam penelitian ini dikenal sebagai konseptual ada pula yang dinyatakan dalam bentuk persamaaan matematika sederhana yang dalam penelitian ini disebut pemahaman algoritma. Selain itu materi ini berkaitan dengan cara memecahkan soal-soal yang terdiri dari angka-angka namun tetap memperhatikan fakta-fakta, aturan-aturan dan peristilahan kimia, sehingga untuk memahaminya siswa memerlukan pemahaman konseptual dan algoritma yang baik.

Konseptual berarti hal-hal yang berkaitan dengan konsep. Pemahaman merupakan kemampuan untuk menangkap makna dan arti dari bahan yang dipelajari (Wingkel, 1996: 24), sehingga pemahaman konseptual adalah pengertian seseorang tentang arti, sifat dan uraian tentang konsep tertentu. Kajian dalam ilmu kimia dimulai dari kajian tentang konsep (Effendy, 2002:3), sehingga pemahaman tentang konsep kimia sangat diperlukan oleh siswa untuk dapat mempelajari materi kimia dengan baik. Hal ini sesuai dengan yang disebutkan oleh Lin dan Cheng (2000: 235), pemahaman konsep sudah menjadi suatu kebutuhan dalam mempelajari konsep kimia yang telah diterima oleh siswa. Siswa dapat dikatakan memahami suatu konsep apabila siswa dapat menjelaskan pengertian konsep tersebut dengan kata-katanya sendiri tanpa mengurangi makna sebenarnya. Berdasarkan uraian di atas, pemahaman siswa terhadap konsep kimia sangat dibutuhkan untuk mempelajari ilmu kimia. Pemahaman konsep yang benar, akan membantu siswa memahami dan mempelajari ilmu kimia yang kebanyakan konsepnya bersifat abstrak dan beberapa soal kimia tidak lepas dari hitungan.

Pada materi kimia banyak dipelajari konsep-konsep yang kompleks dan abstrak, sehingga memerlukan suatu alat bantu untuk dapat menyederhanakan dan memudahkan agar dapat dipahami dengan baik. Alat bantu yang dimaksud dapat berupa suatu model, misalnya model atom dan ada juga model berupa rumus matematika. Prosedur atau serangkaian peraturan (rumus matematik) untuk menghitung atau memecahkan masalah disebut algoritma. Rumus matematika menyatakan hubungan kuantitatif antara sifat-sifat materi yang dipaparkan dengan huruf dan angka, sehingga pemahaman algoritma adalah kemampuan untuk menangkap makna dan arti dari bahan yang dipelajari melalui serangkaian peraturan (rumus matematik) untuk menghitung atau memecahkan masalah.

Berdasarkan uraian di atas pemahaman konseptual yang benar, akan membantu siswa memahami dan mempelajari ilmu kimia yang kebanyakan konsepnya bersifat abstrak dan soal-soal kimia tidak lepas dari hitungan. Oleh karena itu, dibutuhkan pemahaman konsep yang kuat untuk menyelesaikan soal hitungan. Selain itu, pemahaman algoritma untuk menyelesaikan soal hitungan kimia juga diperlukan oleh siswa. Apabila siswa tidak mengikuti langkah-langkah memecahkan soal kimia 
dengan menggunakan algoritma secara benar maka siswa akan kesulitan untuk menyelesaikan soal tersebut. Kedua pemahaman ini dibangun berdasarkan hasilhasil observasi tentang karakteristik dasar dari peristiwa kelarutan, sehingga diperkirakan ada hubungan yang erat antara pemahaman konseptual dengan pemahaman algoritma dalam memahami materi kelarutan dan hasil kali kelarutan.

Kesulitan dalam mempelajari kimia dapat disebabkan oleh beberapa hal, baik ditinjau dari perilaku siswa dalam belajar kimia maupun sifat, konsep, prinsip dan teori dari ilmu kimia itu sendiri. Menurut Kean dan Middlekamp (1985: 6-11) ilmu kimia sulit dipelajari siswa karena 5 hal pokok yaitu (1) Sebagian besar konsep kimia bersifat abstrak; (2) konsep-konsep kimia adalah penyederhanaan dari yang sebenarnya; (3) materi kimia bersifat berurutan; ( 4) ilmu kimia tidak hanya sekedar memecahkan soal-soal numerik (terdiri dari angka-angka saja); (5) beban yang harus dipelajari dalam mata pelajaran kimia sangat banyak. Kemampuan berpikir abstrak dan pemahaman konsep sangat diperlukan agar dapat mempelajari ilmu kimia dengan benar. Berdasarkan penjelasan tersebut untuk dapat belajar kimia dengan baik seorang siswa harus sudah mencapai tingkat berfikir formal menurut kategori kematangan intelektual Piaget, serta disampaikan berdasarkan prinsip-prinsip pembelajaran konstruktivistik.

Beberapa penelitian menunjukkan bahwa materi kelarutan dan hasil kali kelarutan cukup sulit untuk dipelajari siswa. Tacettin \& Canpolat (2003) menyatakan bahwa siswa mengalami kesulitan dalam memahami materi kelarutan dan hasil kali kelarutan, sehingga menyebabkan terjadinya kesalahan konsep. Onder \& Geban (2006) menyatakan bahwa siswa mengalami kesulitan memahami keadaan dinamis setelah kesetimbangan larutan tercapai dan kesulitan menyelesaikan soalsoal Ksp. Nisak (2010) menyatakan bahwa $45,2 \%$ siswa SMA Labratorium UM mengalami kesulitan dalam menentukan kelarutan senyawa dalam pelarut air dan $75,5 \%$ siswa mengalami kesulitan dalam menentukan kelarutan zat dalam larutan yang mengandung ion senama. Upaya untuk mengatasi kesulitan belajar siswa adalah dengan menerapkan kegiatan pembelajaran yang dapat menarik minat siswa untuk belajar yang di dalamnya dapat menggunakan strategi-strategi pembelajaran berbasis konstruktivistik (Iskandar, 2011).

Inkuiri terbimbing merupakan salah satu strategi pembelajaran berbasis konstruktivistik yang dapat digunakan pada materi kelarutan dan hasil kali kelarutan. Sanjaya (2008) mengungkapkan bahwa pembelajaran inkuri sebagai rangkaian kegiatan pembelajaran yang menekankan pada proses berpikir kritis dan analitis siswa untuk mencari dan menemukan jawaban dari suatu masalah yang dipertanyakan. Cacciatore dkk (2008) menyatakan bahwa inkuiri merupakan strategi yang tepat untuk mengajarkan sains. Karakteristik materi kelarutan dan hasil kali kelarutan yang mengandung konsep konkrit, abstrak, dan algoritmik dinilai sesuai dengan strategi inkuiri terbimbing. Kesesuaian ini merujuk pada pola strategi inkuiri terbimbing yang pembelajarannya dimulai dari hal-hal yang bersifat konkrit kemudian menuju hal-hal yang bersifat abstrak. Strategi inkuiri terbimbing pada penelitian ini menggunakan langkah-langkah pembelajaran yang diadaptasi dari penjelasan Hanson (2005:1), seperti dijabarkan sebagai berikut.

Tahap pengarahan, pada tahap ini dimulai dengan mempersiapkan siswa untuk belajar, memberikan motivasi, menimbulkan minat dan rasa ingin tau, menggali pengetahuan awal, dan menghubungkan pengetahuan yang akan dipelajari dengan pengetahuan awal siswa sebelumnya. Selanjutnya disampaikan tujuan pembelajaran, indikator keberhasilan yang harus dicapai, informasi-informasi, dan sumber referensi yang dibutuhkan selama proses belajar mengajar. Siswa diberikan pertanyaan-pertanyaan yang bersifat menggali, memfokuskan serta mengarahkan siswa pada pokok masalah yang akan dikaji.

Tahap eksplorasi, pada tahap ini siswa diberikan kesempatan untuk melakukan 
pengamatan, merancang eksperimen, meneliti dan menganalisis sumber data atau informasi, menyelidiki hubungan, memberikan pendapat, pertanyaan dan menguji hipotesis.

Tahap pembentukkan konsep, pada tahap ini konsep ditemukan, diperkenalkan dan dibentuk sebagai hasil dari eksplorasi. Proses ini dirancang dengan memberikan beragam pertanyaan-pertanyaan yang mendorong siswa berpikir kritis dan analitis sesuai dengan hasil eksplorasi.

Tahap aplikasi, tahap ini melibatkan aplikasi pengetahuan baru yang diperoleh siswa selama proses latihan maupun pemecahan masalah.

Tahap penutup, tahap ini merupakan bagian akhir kegiatan siswa yaitu memvalidasi hasil belajarnya, merenungkan apa yang telah mereka pelajari, dan melakukan penilaian terhadap kinerjanya.

Strategi pembelajaran lain yang juga berbasis konstruktivistik yang dapat digunakan pada materi kelarutan dan hasil kali kelarutan adalah Problem Solving. Menurut Bodner \& Herron (2002); BouJaoude \& Barakat (2003) mengemukakan bahwa penerapan Problem Solving dalam pembelajaran dapat membantu siswa untuk meningkatkan kemampuan dalam memecahkan masalah. Cardellini (2006) menyatakan bahwa dalam Problem Solving tidak hanya membutuhkan kemampuan dalam berhitung, tetapi juga kemampuan menganalisis, merencanakan, dan mengevaluasi hingga membuat kesimpulan. Strategi Problem Solving ini dinilai sesuai dengan karakteristik materi kelarutan dan hasil kali kelarutan yang membutuhkan beragam kemampuan kognitif untuk mempelajarinya. Langkahlangkah pembelajaran dalam strategi Problem Solving menurut Polya (2004) dijabarkan sebagai berikut.

Tahap memahami masalah, pada tahap ini siswa diberikan masalah sehingga tujuan dapat teridentifikasi, selanjutnya siswa di arahkan untuk membaca dan memahami masalah sampai menemukan solusi yang tepat untuk memecahkannya.

Tahap merancang solusi, pada tahap ini siswa menemukan unsur-unsur penting, menguraikan masalah, dan mencoba untuk mengidentifikasi strategi pemecahan yang tepat. Siswa menggunakan perkiraan solusi untuk memecahkan masalah, sehingga tujuan dari masalah menjadi jawaban perkiraan/sementara bukan jawaban pasti.

Tahap melaksanakan solusi, pada tahap ini siswa memeriksa langkah demi langkah pada solusi yang diajukan dan apabila rencana yang disusun tidak dapat menyelesaikan masalah maka mencari solusi yang lain. Penyelesaian masalah dapat berupa penyelesaian secara kuantitatif atau kualitatif. Penyelesaian kuantitatif berupa penggunaan rumus yang sesuai. Sedangkan penyelesaian kualitatif dapat dilakukan dengan penyimpulan dan logika.

Tahap review, pada tahap ini siswa mengevaluasi hasil yang diperoleh (masuk akal atau tidak) dan membuat kesimpulan dari hasil yang diperoleh, serta dapat memberikan alternatif solusi untuk memecahkan masalah.

Penelitian-penelitian tentang strategi inkuiri terbimbing dan strategi Problem Solvingse belumnya telah dilakukan oleh beberapa peneliti secara terpisah. Penelitian tentang penggunaan strategi inkuiri terbimbing pada topik berbeda antara lain dilakukan Agustina (2009) dan Ambarwati (2015). Penelitian tentang penggunaan strategi Problem Solving pada topik berbeda antara lain dilakukan oleh Mustapa (2009), dan Irawati (2014). Hasilhasilpenelitian tersebut menyebutkan bahwa kedua strategi pembelajaran konstruktivistik tersebut efektif untuk meningkatkan hasil belajar siswa.

Beberapa peneliti juga telah melakukan penelitian tentang pemahaman konseptual dan pemahaman algoritma. Nakleh (1993:55). menunjukkan bahwa kemampuan pemahaman konseptual siswa tertinggal daripada kemampuan pemahaman siswa dalam memecahkan soalsoal algoritma tentang hukum gas. Begitu juga dengan penelitian Bakar (2006: 61) menunjukkan hasil yang sama bahwa kemampuan konseptual siswa kelas II SMAN 4 Malang pada materi stoikiometri cenderung tertinggal dibandingkan kemampuan algoritmanya. Berdasarkan pada beberapa fakta tersebut, siswa dalam mengerjakan soal hitungan kimia tanpa 
memahami konsep kimia dengan baik. Siswa hanya berpegang pada rumus yang ada untuk menyelesaikan soal hitungan kimia.Hasil dari penelitian-penelitian tersebut menyatakan bahwa terdapat korelasi yang positif antara pemahaman konseptual dengan pemahaman algoritma. Berdasarkan uraian tersebut, maka perlu dilakukan penelitian untuk mengetahui perbedaan strategi inkuiri terbimbing dan Problem Solving terhadap pemahaman konseptual dan pemahaman algoritma siswa dengan KBIR.

\section{METODE}

Rancangan yang digunakan dalam penelitian ini adalah rancangan eksperimen semu dengan melibatkan dua kelas eksperimen sebagai sampel penelitian. Kelas eksperimen pertama menggunakan strategi inkuiri terbimbing dan kelas eksperimen kedua menggunakan strategi Problem Solving. Rancangan penelitian ini digunakan untuk membandingkan strategi inkuiri terbimbing dengan strategi Problem Solving. Selain itu juga membandingkan pemahaman konseptual dan pemahaman algoritma siswa dengan kemampuan berpikir ilmiah rendah. Penelitian ini menggunakan rancangan posttest only control group design. Rancangan penelitian yang digunakan seperti pada Tabel 1.

Tabel 1. Rancangan Posttest Only Control Group Design

\begin{tabular}{|c|c|c|}
\hline Perlakuan & \multicolumn{2}{|c|}{ Posttest } \\
\hline $\mathrm{O}_{1}$ & $\mathrm{O}_{2}$ & $\mathrm{O}_{3}$ \\
\hline $\mathrm{O}_{4}$ & $\mathrm{O}_{5}$ & $\mathrm{O}_{6}$ \\
\hline
\end{tabular}

Keterangan

$\mathrm{O}_{1}=$ Strategi inkuiri terbimbing

$\mathrm{O}_{2}=$ Skor pemahaman konseptual siswa yang dibelajarkan dengan strategi inkuiri terbimbing

$\mathrm{O}_{3}=$ Skor pemahaman algoritma siswa dengan KBIR yang dibelajarkan dengan strategi inkuiri terbimbing

$\mathrm{O}_{4}=$ Strategi Problem Solving

$\mathrm{O}_{5}=$ Skor pemahaman konseptual siswa dengan KBIR yang dibelajarkan dengan strategi Problem Solving
$\mathrm{O}_{6}=$ Skor pemahaman algoritma siswa dengan KBIR yang dibelajarkan dengan strategi Problem Solving

Subjek dari penelitian ini adalah siswa kelas XI IPA SMA Negeri Pronojiwo Lumajang tahun ajaran 2014/2015 yang terdiri dari 2 kelas. Teknik sampling yang digunakan adalah teknik sampling jenuh dimana semua anggota populasi dijadikan subjek. Teknik sampling ini memungkinkan untuk membuat generalisasi dengan kesalahan yang sangat kecil.

Data penelitian yang dikumpulkan meliputi skor kemampuan berfikir ilmiah, skor tes pemahaman konseptual dan skor pemahaman algoritma siswa. Instrumen yang digunakan dalam penelitian ini adalah tes berpikir ilmiah (Classroom Test of Scientific Reasoning) dan tes hasil belajar siswa. Instrumen tes berpikir ilmiah yang digunakan dalam penelitianini adalah hasil adopsi ke dalam bahasa Indonesia dari Classroom Test of Scientific Reasoning yang dikembangkan oleh Lawson (2000) berjumlah 24 item soal pilihan ganda dengan koefisienreliabilitassebesar 0,74 . Instrumen tes hasil belajar berupa soal pilihan ganda yang terdiri dari 20 item soal pilihan ganda yang terdiri dari 10 soal pemahaman konseptual dan 10 soal pemahaman algoritma dengan jenjang soal mulai $\mathrm{C} 1$ hingga $\mathrm{C} 4$ yang dikembangkan berdasarkan indikator pembelajaran pada materi kelarutan dan hasil kali kelarutan dengan nilai reliabilitas sebesar 0,71 . Reliabilitas instrumen diukur dengan bantuan program SPSS Statistics 16 for Windows.

Teknik analisis data pada penelitian ini bertujuan untuk menguji: (1) perbandingan strategi inkuiri terbimbing dengan strategi Problem Solving terhadap hasil belajar siswa dengan KBIR; (2) perbandingan pemahaman konseptual dengan pemahaman algoritma siswa dengan KBIR, baik pada kelas inkuiri terbimbing maupun pada kelas Problem Solving. Analisis data dalam penelitian ini menggunakan uji statistik non parametrik, sehingga peneliti tidak perlu lagi melihat apakah data/skor tes distribusinya normal atau tidak, homogen atau tidak, dan tidak harus interval. Uji hipotesis rumusan masalah 1 menggunakan 
uji t, sedangkan rumusan masalah 2 menggunakan korelasi Product Moment dengan taraf signifikan $\alpha=0,05$ dengan bantuan program SPSS 16 for Windows.

\section{HASIL DAN PEMBAHASAN}

Data kemampuan awal siswa diperoleh dari hasil nilai tes materi sebelumnya yaitu hidrolisis garam. Data kemampuan awal siswa kelas XI IPA 1 atau kelas inkuiri terbimbing dan kelas XI IPA 2 atau kelas Problem Solving dijabarkan pada Tabel 2.

Tabel 2. Data Kemampuan Awal Siswa

\begin{tabular}{|l|c|c|}
\hline Keterangan & $\begin{array}{c}\text { Kelas } \\
\text { Inkuiri } \\
\text { Terbimbing }\end{array}$ & $\begin{array}{c}\text { Kelas } \\
\text { Problem } \\
\text { Solving }\end{array}$ \\
\hline Jumlah Siswa & 22 & 23 \\
\hline Mean & 67,45 & 65,56 \\
\hline Minimum & 52 & 52 \\
\hline Maksimum & 88 & 84 \\
\hline
\end{tabular}

Berdasarkan Tabel 2 diketahui bahwa rata-rata nilai kemampuan awal siswa kedua kelas tidak berbeda jauh, sehingga dapat disimpulkan siswa kelas inkuiri terbimbing dan kelas problem solving memiliki kemampuan yang hampir sama..

Pada penelitian ini data Kemampuan Berfikir Ilmiah siswa (KBI) diperoleh dari skor Tes Berfikir Ilmiah (TBI). Data skor TBI siswa kelas inkuiri terbimbing dan siswa kelas kelas Problem Solving dijabarkan pada Tabel 3.

Tabel 3. Data Skor Tes Berfikir Ilmiah Siswa

\begin{tabular}{|c|c|c|c|}
\hline \multirow{2}{*}{\multicolumn{2}{|c|}{ Keterangan }} & \multicolumn{2}{|c|}{ Kelas } \\
\hline & & \multirow{2}{*}{$\begin{array}{c}\begin{array}{c}\text { Inkuiri } \\
\text { terbimbing }\end{array} \\
43,56\end{array}$} & \multirow{2}{*}{$\begin{array}{c}\begin{array}{c}\text { Problem } \\
\text { Solving }\end{array} \\
44,57\end{array}$} \\
\hline $\begin{array}{l}\text { Skor } \mathrm{T} \\
\text { rata }\end{array}$ & I rata- & & \\
\hline \multirow{2}{*}{$\begin{array}{l}\text { Jumlah } \\
\text { Siswa }\end{array}$} & KBIT & 12 & 13 \\
\hline & KBIR & 10 & 10 \\
\hline \multicolumn{2}{|c|}{ Skor minimum } & 29,17 & 29,17 \\
\hline \multicolumn{2}{|c|}{ Skor Maksimum } & 54,17 & 58,33 \\
\hline
\end{tabular}

Berdasarkan Tabel 3 diketahui bahwa rata-rata skor TBI siswa kelas inkuiri terbimbing hampir sama dengan rata-rata nilai KBI siswa kelas Problem Solving, sehingga dapat disimpulkan siswa pada kelas inkuiri terbimbing dan kelas Problem Solving memiliki KBI yang hampir sama. Kemudian siswa dengan skor TBI sama dengan atau di atas rata-rata skor kelas dikelompokkan ke dalam kelompok kemampuan berpikir ilmiah tinggi (KBIT). Siswa dengan skor TBI di bawah rata-rata skor kelas dikelompokkan ke dalam kelompok kemampuan berpikir ilmiah rendah (KBIR). Dalam penelitian ini yang digunakan untuk penelitian hanya siswa dengan KBIR.

Data pemahaman konseptual dan pemahaman algoritma siswa diperoleh dari hasil tes materi kelarutan dan hasil kali kelarutan. Data hasil tes pemahaman konseptual dan pemahaman algoritma kelas inkuiri terbimbing dan kelas Problem Solving siswa dengan KBIR pada materi kelarutan dan hasil kali kelarutan ditunjukkan pada Tabel 4 dan Tabel 5.

Tabel 4. Data Hasil Tes Siswa Kelas Inkuiri Terbimbing dan Problem Solving

\begin{tabular}{|l|c|c|}
\hline \multicolumn{1}{|c|}{ Keterangan } & $\begin{array}{c}\text { Kelas } \\
\text { Inkuiri } \\
\text { Terbimbing }\end{array}$ & $\begin{array}{c}\text { Kelas } \\
\text { Problem } \\
\text { Solving }\end{array}$ \\
\hline Jumlah Siswa & 10 & 10 \\
\hline Skor Minimum & 59 & 50 \\
\hline Skor Maksimum & 82 & 82 \\
\hline Skor rata-rata & 69 & 63,5 \\
\hline
\end{tabular}

Tabel 5. Data Hasil Tes Pemahaman Konseptual dan Algoritma Siswa Kelas Inkuiri Terbimbing dan Problem Solving

\begin{tabular}{|l|c|c|}
\hline Keterangan & $\begin{array}{c}\text { Kelas } \\
\text { Inkuiri } \\
\text { Terbimbing }\end{array}$ & $\begin{array}{c}\text { Kelas } \\
\text { Problem } \\
\text { Solving }\end{array}$ \\
\hline Jumlah Siswa & 10 & 10 \\
\hline $\begin{array}{l}\text { Skor rata-rata } \\
\text { Konseptual }\end{array}$ & 65 & 56 \\
\hline $\begin{array}{l}\text { Skor rata-rata } \\
\text { Algoritma }\end{array}$ & 73 & 71 \\
\hline
\end{tabular}

Berdasarkan Tabel 4 dan 5 diketahui bahwa nilai rata-rata tes siswa kelas inkuiri terbimbing lebih tinggi dibandingkan nilai rata-rata kelas Problem Solving, sedangkan hasil tes pemahaman konseptual dan pemahaman algoritma di kelas inkuiri terbimbing lebih tinggi dibandingkan kelas Problem Solving. Dalam hal ini dapat disimpulkan bahwa pemahaman konseptual dan pemahaman algoritma siswa dengan KBIR yang dibelajarkan dengan strategi inkuiri terbimbing lebih baik dibandingkan 
dengan siswa yang dibelajarkan dengan strategi Problem Solving.

Berdasarkan data-data yang sudah dikumpulkan, maka selanjutnya dilakukan uji hipotesis menggunakan uji $\mathrm{t}$ dan uji korelasi Product Moment. Hasil uji t dan uji korelasi Product Moment ditunjukkan pada Tabel 6 dan Tabel 7.

Tabel 6. Hasil Uji t Pengaruh Strategi

Pembelajaran Terhadap Pemahaman Konseptual dan Algoritma Siswa

\begin{tabular}{|l|l|l|}
\hline Parameter & $\begin{array}{l}\text { Dependent } \\
\text { Variable }\end{array}$ & p (sig) \\
\hline Strategi Belajar & $\begin{array}{l}\text { Hasil Tes } \\
\text { Pemahaman }\end{array}$ & 0,482 \\
\hline
\end{tabular}

Tabel 7 Hasil Uji Koefisien Korelasi Product Moment

\begin{tabular}{|l|l|l|l|}
\hline Sig & $\mathbf{N}$ & $\mathbf{r}_{\mathbf{x y}}$ & keterangan \\
\hline 0,000 & 20 & 0,654 & $\begin{array}{l}\text { Hubungan } \\
\text { tinggi }\end{array}$ \\
\hline
\end{tabular}

Berdasarkan Tabel 6 dan Tabel 7 maka dapat diketahui hal-hal sebagai berikut: (1) hasil uji t diperoleh $\mathrm{p}$ (sig) sebesar 0,482 dan (2) hasil uji korelasi Product Moment diperoleh $\mathrm{r}$ sebesar 0,654

\section{Perbandingan Hasil Belajar Siswa dengan KBIR yang dibelajarakan menggunakan Strategi Inkuiri Terbimbing dengan Strategi Problem Solving}

Berdasarkan data pada Tabel 4 yang menunjukkan data skor hasil tes siswa kelas inkuiri terbimbing dan Problem Solving maka dapat digambarkan dengan grafik seperti Gambar 1.

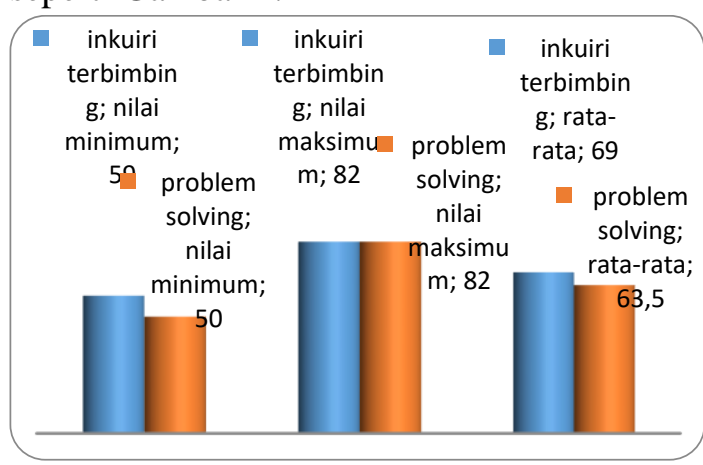

Gambar 1.Grafik Skor Hasil Tes Siswa Kelas Inkuiri Terbimbing dan Problem Solving
Berdasarkan Gambar 1 dapat diketahui bahwa skor hasil tes pemahaman konseptual dan pemahaman algoritma siswa dengan KBIR yang dibelajarkan menggunakan strategi inkuiri terbimbing secara umum lebih tinggi dibandingkan dengan yang dibelajarkan menggunakan strategi Problem Solving. Hal ini ditunjukkan dengan rata-rata nilai hasil tes siswa kelas inkuiri terbimbing sebesar 69, lebih tinggi dibandingkan kelas Problem Solving yang hanya sebesar 63,5.

Berdasarkan Tabel 6 diketahui hasil uji $\mathrm{t}$ tentang pengaruh strategi pembelajaran terhadap hasil belajar siswa diperoleh nilai p (sig) > $(0,05)$. Hal ini menunjukkan bahwa ada perbedaan yang signifikan antara hasil belajar siswa yang dibelajarkan menggunakan strategi inkuiri terbimbing dengan siswa yang dibelajarkan menggunakan strategi Problem Solving. Dengan demikian dapat dikatakan bahwa pembelajaran menggunakan strategi inkuiri terbimbing lebih efektif diterapkan pada siswa dengan KBIR pada materi kelarutan dan hasil kali kelarutan.

Hasil penelitian yang diperoleh diatas sesuai dengan teori yang dikemukakan oleh Lundgren (1991) dalam Mc Daniel \& Green (2012: 3), bahwa penerapan pembelajaran berbasis inkuiri terbimbing memiliki beberapa keuntungan, yang salah satunya adalah meningkatkan prestasi akademik siswa. Penelitian sebelumnya yang dilakukan oleh Rini (2013), juga menunjukkan kesesuaian yaitu, bahwa strategi pembelajaran inkuiri terbimbing dapat meningkatkan hasil belajar kognitif siswa pada materi kelarutan dan hasil kali kelarutan. Selain itu hasil penelitian ini juga mendukung hasil penelitian Maikristina (2013) yang menyatakan bahwa hasil belajar kognitif siswa yang dibelajarkan menggunakan strategi inkuiri terbimbing lebih tinggi dibandingkan hasil belajar siswa yang dibelajarkan menggunakan strategi Problem Solving.

\section{Perbedaan Pemahaman Konseptual dan Algoritma Siswa dengan KBIR}

Pada Tabel 5 dijabarkan data skor hasil tes pemahaman konseptual dan pemahaman algoritma siswa di kedua kelas ekperimen 
maka dapat digambarkan dengan grafik seperti pada Gambar 2 berikut.

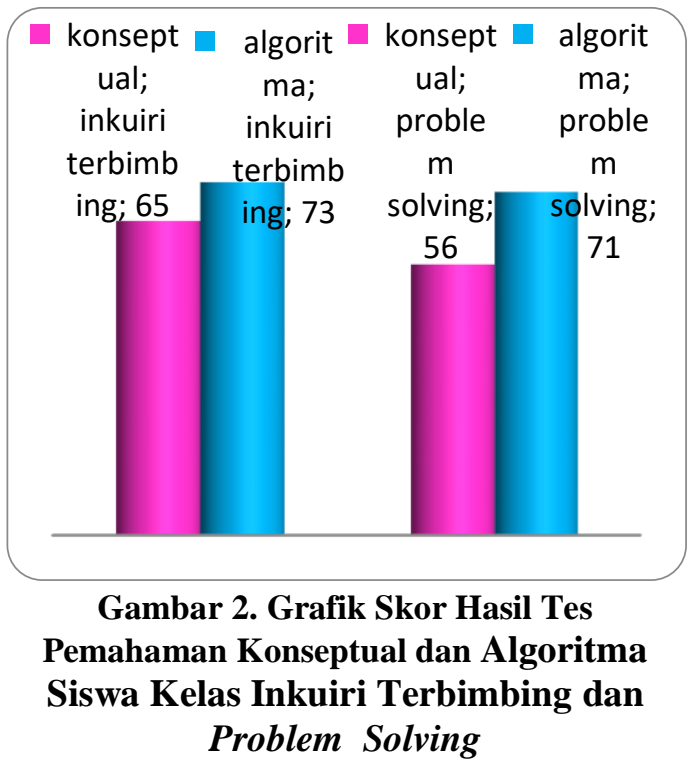

Berdasarkan Gambar 2 dapat diketahui bahwa rata-rata nilai hasil tes pemahaman algoritma siswa kelas inkuiri terbimbing sebesar 73, lebih tinggi dibandingkan pemahaman konseptualnya yang hanya sebesar 65. Hal yang sama juga terjadi pada kelas Problem Solving, rata-rata nilai hasil tes pemahaman algoritma sebesar 71 lebih tinggi dibandingkan pemahaman konseptualnya yang hanya sebesar 56. Hasil tes pemahaman algoritma di kelas inkuiri terbimbing tidak berbeda terlalu jauh dengan kelas Problem Solving yaitu ratarata sebesar 73 dan 71. Hasil tersebut berbeda dengan nilai tes pemahaman konseptual di kelas inkuiri dengan rata-rata 65 yang lebih tinggi dibandingkan dengan kelas Problem Solving sebesar 56.

Hasil-hasil tersebut menunjukkan bahwa pemahaman algoritma siswa dengan KBIR lebih tinggi dibandingkan pemahman konseptualnya. Dengan kata lain pemahaman algoritma lebih dikuasai siswa dibandingkan pemahaman konseptualnya . Hal ini dimungkinkan karena siswa lebih mudah dalam menyelesaikan soal hitungan kimia dibandingan soal konsep, karena siswa hanya dituntut untuk hafal rumus hitungan tanpa harus memahami konsepnya. Pemahaman algoritma seharusnya didasari dengan pemahaman konseptual, tetapi ada soal-soal kimia yang dapat diselesaikan tanpa pemahaman konseptual. Hal tersebut sesuai dengan pernyataan Schmidt (dalam Esnawi, 2006:7) bahwa banyak soal-soal kimia yang dapat diselesaikan tanpa harus memiliki pemahaman konseptual yang baik.

Beberapa penelitian yang sudah dilakukan sebelumnya seperti penelitian Nakleh (1993:55), menyatakan bahwa pemahaman konseptual siswa tertinggal dibandingkan pemahaman siswa dalam memecahkan soal-soal algoritma tentang hukum gas. Penelitian Bakar (2006: 61), menunjukkan hasil yang sama bahwa kemampuan konseptual siswa kelas II SMAN 4 Malang pada materi stoikiometri cenderung tertinggal dibandingkan kemampuan algoritmanya. Berdasarkan pada beberapa fakta tersebut, siswa mengerjakan soal hitungan kimia tanpa memahami konsep kimia dengan baik atau siswa hanya berpegang pada rumus yang ada untuk menyelesaikan soal hitungan kimia.

Hasil perhitungan uji korelasi Product Moment menunjukkan nilai sebesar 0,654 pada taraf signifikan 0,05. Hal ini menunjukkan adanya hubungan kesejajaran antara pemahaman konseptual dengan pemahaman algoritma siswa atau dengan kata lain, pemahaman konseptual yang baik akan meningkatkan pemahaman algoritma. Sehingga dapat disimpulkan ada hubungan tinggi antara pemahaman konseptual dan pemahaman algoritma siswa dengan KBIR pada materi kelarutan dan hasil kali kelarutan.

\section{SIMPULAN}

Berdasarkan hasil penelitian dan pembahasan yang telah dijabarkan sebelumnya, dapat disimpulkan bahwa hasil belajar siswa dengan KBIR yang dibelajarkan menggunakan strategi inkuiri terbimbing lebih tinggi dibandingkan dengan siswa yang dibelajarkan menggunakan strategi Problem Solving pada materi kelarutan dan hasil kali kelarutan. Pemahaman algoritma siswa dengan KBIR secara umum lebih baik dibandingkan pemahaman konseptualnya baik di kelas inkuiri terbimbing maupun kelas Problem Solving. Pemahaman 
konseptual dan algoritma saling berhubungan dalam memahami materi kimia atau dengan kata lain, pemahaman konseptual yang baik akan meningkatkan pemahaman algoritma.

Berdasarkan kesimpulan tersebut maka saran bagi pengajar kimia adalah sebelum pembelajaran berlangsung hendaknya memperhatikan kemampuan berpikir ilmiah siswa berbeda-beda, sehingga dapat menggunakan langkah-langkah

\section{DAFTAR PUSTAKA}

Agustina, R. 2013. Efektivitas Pembelajaran Kimia dengan Pendekatan Inkuiri Terbimbing Berbantuan Media Animasi Digital terhadap Motivasi dan Hasil Belajar Siswa pada Pokok Bahasan Laju Reaksi.Tesis tidak diterbitkan: PPS Universitas Negeri Malang.

Ambarwati, I. 2015. Pengaruh Strategi Pembelajaran Inkuiri Terbimbing disertai Peta Konsep terhadap Hasil Belajar Siswa Pada Materi Laju Reaksi ditinjau dari Perbedaan Kemampuan Berpikir Ilmiah. Tesis tidak diterbitkan: PPS Universitas Negeri Malang.

Bakar, A. 2006. Pengaruh Remidi Menggunakan Metode Problem Solving dan Tingkat Intelek terhadap Hasil Belajar dan Menyelesaikan Soal Konseptual dan Algoritma pada Topik Stoikiometri Siswa Kelas II SMA Negeri 4 Malang. Tesis tidak diterbitkan. Malng: Program Pasca Sarjana Universitas Negeri Malang.

Bao, L., Cai, T., Koenig, K., Fang, K., Han, J., Wang, J., Liu, Q., Ding, I., Coi, L., Luo, Y., Wang, Y., Li, L., \& Wu, N. 2009. Learning and Scientific Reasoning. Science, 323,1-9.

Bodner, G.M. \& Herron, J.D. 2002. Problem Solving in Chemistry. Chemistry Education: Research based Practice, 7:70-81.

BouJaoude, S. danBarakat, H. 2003.Students' Problem Solving Strategies in Stoichiometry and their Relationships to Conceptual Understanding and Learning pembelajaran kimia yang sesuai untuk siswa. Strategi inkuiri terbimbing dan Problem Solving dapat menjadi referensi dalam pembelajaran untuk meningkatkan hasil belajar siswa dengan KBIR. Bagi peneliti selanjutnya, agar dapat melanjutkan penelitian ini dengan menggunakan strategi lain dan memberikan pengajaran yang lebih baik sehingga dapat meningkatkan pemahaman konseptual dan pemahaman algoritma siswa dengan KBIR.

Approaches.Electronic Journal of Science Education, 7(3): 1-42.

Cacciatore, K.L., Amado, J., Evans, J.J. 2008. Connecting Solubility, Equilibrium, and Perodicity in a Green, Inquiry Experiment for the General Chemistry Laboratory. Journal of Chemical Education, 85(2): 251-253.

Cardellini, L. 2006. Fostering Creative Problem Solving in Chemistry Through Group Work. Chemistry Education Research and Practice, 7: 131-140.

Effendy. 2006. A-Level chemistry for Senior High School Students, Volume 1A. Malang: Bayumedia Publishing.

Esnawi. 2006. Analisis Pemahaman Konseptual dan Algoritmik Materi Laju Reaksi Ditinjau dari Tingkat Berpikir Formal Mahasiswa Program Studi Pendidikan Kimia Universitas Haluoleo. Tesis tidak diterbitkan. Malang: PPS UM.

Hanson, D.M. 2005. Designing ProcessOriented Guided-Inquiry Activities. In S. W. Bayerlein \& D.K. Apple (Eds). IL: Pacific Crest.

Irawati, R.K. 2014. Pengaruh Metode Problem Solving dan Problem Posing sertaKemampuanAwalTerhadap Hasil Belajar Siswa pada Materi KelarutandanHasilKaliKelarutan. Tesis tidak diterbitkan: PPS Universitas Negeri Malang.

Iskandar, S.M. 2011. Pendekatan Pembelajaran Sains Berbasis Konstruktivis. Malang: Bayumedia.

Kean, E. \& Middlecamp, C. 1985. Panduan Belajar Kimia. Jakarta: PT Gramedia. 
Lawson, A.E. 2000. Classroom Test of Scientific Reasoning, (Online), (http://lsweb.la.asu.edu/alawson/Laws onAssesments.htm, diakses 21 Juni 2013).

Maikristina, N. 2013. Pengaruh Penggunaan Model Pembelajaran Inkuiri Terbimbing Terhadap Hasil Belajar dan Keterampilan Proses Sains Siswa Kelas XI IPA SMA 3 Malang Pada Materi Hidrolisis Garam. Skripsi tidak diterbitkan. Universitas Negeri Malang.

McDaniel, S. \& Green, L. 2012. Independent Interactive Inquiry-Based Learning Modules Using Audio-Visual Instruction In Statistics. Journal of Education, (Online), 6(1):2-18, (http://www.escholarship.org/uc/item/3 22385kq), diakses 1 Mei 2013.

Mustapa, K. 2009. Efektivitas Pembelajaran Problem Posing dalam Meningkatkan Proses Belajar, Motivasi, dan Hasil Belajar Mahasiswa Pada Mata Kuliah Kimia Dasar I FKIP Universitas Tadulako. Tesis tidak diterbitkan. Malang: PPS Universitas Negeri Malang.

Nakhleh, M.B \& Mitchell. Why Some Student Don't Learn Chemistry. Journal of Chemical Education. 69(3): 191-195.
Nisak, K. 2010. Identifikasi Kesulitan Belajar Siswa Kelas XI IPA Semester II SMA Laboratorium Universitas Negeri Malang dalam Memahami Materi Kelarutan dan Hasil Kali Kelarutan. Skripsi tidak diterbitkan. Malang: Universitas Negeri Malang.

Onder, I. \& Geban, O. 2006. The effect of conceptual change texts oriented instruction on students' understanding of the solubility equilibrium concept. Journal of education, (Online), No. 30, (http://www.efdergi.hacettepe.edu.tr/2 00630\%C4\%B0L\%20\%C3\%96\%NDE R.pdf, diakses1mei 2013).

Polya, G. 2004. How to Solve It (John Conway, Ed).United State of America: Princenton University Press.

Rini, C.A. 2013. Pengaruh Pendekatan Inkuiri Terbimbing dan Kemampuan Awal Terhadap Hasil Belajar Kognitif Tingkat Tinggi Pada Materi Kelarutan dan Hasil Kali Kelarutan. Tesis. Malang: PPS Universitas Negeri Malang.

Sanjaya, W. 2008. Pembelajaran Dalam Implementasi Kurikulum Berbasis Kompetensi. Jakarta: Kencana Media Group.

Tacettin \& Canpolat. 2003. Student's Understanding of Solution Chemistry Concepts. Journal Chemical Education, 80(11): 1328-1332. 